\title{
DE FOMES, LUTAS E PRIVAÇÕES: A EXPERIÊNCIA NEORREALISTA OU A DOCUMENTAÇÃO DO TEMPO PORTUGUÊS
}

\author{
Michele Dull Sampaio Beraldo Matter \\ (Centro Federal de Educação Tecnológica Celso Suckov)
}

\section{RESUMO}

Este artigo analisa diferentes imagens ligadas ao alimento em obras do $\mathrm{Ne}$ orrealismo português, na sua configuração de falta - a fome - e na sua concepção ideológica - a fome de liberdade e de dignidade - experiência temática que dá a ver intrinsecamente a relação do humano com o seu tempo e com o seu semelhante.

PALAVRAS-CHAVE: Neorrealismo, Ficção vs História, fome.

\begin{abstract}
This article examines different images related to the food in literary texts and paintings of portuguese Neorealism in its configuration of missing - hunger - and its ideological conception - the hunger for freedom and dignity - thematic experience that gives inherently see the relationship of humans with their time and with his fellow man.
\end{abstract}

KEYWORDS: Neorealism, Fiction vs History, Hunger. 
Que o pão encontre na boca o abraço de uma canção construída no trabalho.

Não a fome fatigada de um suor que corre em vão.

Que o pão do dia não chegue sabendo a travo de luta e a troféu de humilhação. Que seja a bênção da flor festivamente colhida por quem deu ajuda ao chão.

Mais do que flor, seja fruto que maduro se oferece, sempre ao alcance da mão.

Da minha e da tua mão.

(Thiago de Mello. O pão de cada dia. In: Faz escuro mas eu canto, 1966)

O desejo do eu-lírico do poema "O pão de cada dia", do poeta amazonense Thiago de Mello, poderia ser facilmente reconhecido como anseio semelhante ao de uma certa produção literária portuguesa que procurou usar sua palavra como grito em defesa do homem e da sua dignidade, produzindo uma literatura compromissada com o social e com a documentação da realidade, em especial, a do tempo histórico português essencialmente ligado ao Salazarismo. De fato, os grandes autores do Neorrealismo literário português procuraram, sem abdicar das preocupações estéticas comuns à Arte, praticar uma escrita ética fundada na crença no homem como possível transformador da realidade, apesar das poderosas forças de condicionamento socioeconômico que determinavam seu destino. Tal qual o eu-lírico de Thiago de Mello, o desejo latente nas obras neorrealistas é o de dignidade conquistada pelo homem que não se sujeita eternamente à exploração e o bem comum alcançado com luta e com trabalho, através de uma revolução social coletiva ao alcance de todos. O pão de cada dia, desejante símbolo de um trabalho bem pago, metamorfoseado em flor, colhida por quem na terra trabalha, e depois em fruto, ofertado a si e ao outro, são caras imagens poéticas do exercício do homem que planta e colhe dignamente os frutos de seu trabalho e os compartilha com o próximo. Por isso, é por elas que escolhemos abrir este artigo, para tomá-las de empréstimo para uma análise que, atendendo à provocação deste número da Revista Abril, pretende explorar diferentes obras do Neorrealismo Português, a partir de um recorte temático que se refere justamente às imagens ligadas ao alimento, na sua configuração quase sempre aqui relacionada à de falta, uma vez que a fome é retratada recorrentemente nas obras deste período. 
Como atrás dissemos, as obras neorrealistas nasceram profundamente atadas à experiência ditatorial vivida no Portugal salazarista, chamado pelo professor Josué de Castro de "mortificação coletiva do povo português" (Rodrigues \& Das Neves, 1959, p. 11) em prefácio ao livro $A$ fome em Portugal, publicado no Brasil em 1959, reunindo artigos jornalísticos de denúncia contra a usurpação do poder pelo ditador português e contra a violência e a corrupção utilizadas para a manutenção do Regime. Pelo desejo de denúncia dessa realidade social e de reflexão sobre a relação do homem com o seu tempo, o exercício artístico neorrealista português tematizou a falta, a privação do homem de todos os possíveis referenciais que os tornariam dignos de assim serem chamados, expôs os sintomas da miséria e as consequências de uma política de violência contra o direito de pensar e de viver. Entretanto, em tais obras artísticas eticamente compromissadas também se fez evidente a sagacidade para vencer, a luta pela sobrevivência num todo social construído à sua revelia e a esperança numa vitória possível. Assim, não pretendemos explorar apenas a temática da fome relacionada ao alimento físico, mas também queremos tratar da fome de liberdade e de dignidade que tais obras também retrataram, ${ }^{1}$ e de imagens revolucionárias que indicavam a capacidade humana de adaptação para sobrevivência e já indiciavam uma futura revolução possível.

No âmbito deste artigo, recortaremos alguns exemplos da obra de Manuel da Fonseca, notadamente, dos contos "Névoa", de Aldeia Nova e "Meio pão com recordações", de O Fogo e as Cinzas e de seu romance Seara de Vento. Também compõem o corpus de análise textos do que ousamos chamar de excursão neorrealista ${ }^{2}$ por terem mantido vivo na contemporaneidade o desejo de subversão da realidade através da aprendizagem de uma visão desalienada do sujeito e do outro que o Neorrealismo, como exercício literário, colocou em prática. Para este recorte, escolhemos imagens dos romances O Anjo Ancorado e O Delfim, de José Cardoso Pires, e do romance Levantado do Chão, de José Saramago. O diálogo sempre profícuo entre a Literatura e as outras artes, através aqui de algumas pinturas clássicas do movimento em questão, nos permitirá uma visão mais ampla do Neorrealismo português.

Manuel da Fonseca, autor alentejano, deixou-nos uma arte profundamente ligada ao homem português e à sua terra, abrindo espaço a homens esquecidos da História, figuras da margem - camponeses, vagabundos, loucos, bêbados, mendigos, malteses, moças do Sul, jovens órfãos ou mesmo alguns patrões em desvio -, mas ao mesmo tempo figuras representativas da condição sócio-histórica do português do seu tempo. Os sintomas da miséria em Portugal, ${ }^{3}$ como a mendicância e o recurso à bebida como meio de fuga da realidade assoladora, são evidentes ao longo de uma obra que se revela como um grito contra todas as formas de opressão e de interdição da vida. O conto "Névoa", reunido em Aldeia Nova, traz um significativo registro da condição do homem faminto, que se entrega à bebida como artifício para a existência, e vive de esmolas, mas ao mesmo tempo é 
uma denúncia da exclusão a que é submetido numa sociedade organizada em classes. O protagonista da narrativa é o bêbado Zé Limão, figura metonímica desse universo. Sobre ele a narrativa registra:

Um torpor de febre invadiu-o lentamente. E de novo sentiu a dor aguda da fome. Desde dias que Zé Limão nada comia. Ninguém o chamara a uma porta e de todas as tabernas o corriam como a um cão danado. Isto era o pior de tudo: "Se pudesse beber... um copo ao menos...” (FONSECA, 1996, p. 83)

Zé Limão é um dos muitos personagens que figuram como metonímias do homem desprovido de todos os meios de subsistência, assolado pela fome, e que, sem fé, se entrega à bebida e é visto e tratado aos poucos quase como um animal. O clímax narrativo é o momento em que, após receber uma moeda como esmola, Zé Limão, à procura de um lugar onde beber, se dirige ao "clube da gente rica da vila, ainda aberto àquela hora”( FONSECA, 1996, p. 85), pois “Uma idéia fixa domina-o: lá dentro há vinho e pão!"( FONSECA, 1996, p. 85). O desprezo por gente como Zé Limão por parte da elite da vila reunida no clube é evidente nos olhares de espanto, nos gestos enfáticos (por exemplo: "Um sujeito que escrevia, sentado à mesa do meio da sala de café, surpreendido, pulou da cadeira" - FONSECA, 1996, p. 85), no riso frouxo e nas gargalhadas com que encaram aquela figura destoante ali ("Uma gargalhada solta de pura alegria abre todas as bocas.” FONSECA, 1996, p. 85). O isolamento do indivíduo em "luta" com um outro que o despreza e lhe encara como um "palhaço de circo" é evidente: "Zé Limão olha sem entender. Dez bocas riem-lhe na cara um riso rolado. A mão cai-lhe ao lado da perna."( FONSECA, 1996, p. 85). Entretanto, o que mais provoca comoção no leitor é a frieza de tratamento com que os membros do clube lidam com um homem faminto, que a esmo suplica: “- Eu pago, seu doutor - murmura humildemente. - Vinho... Eu pago..." (FONSECA, 1996, p. 85), ou, na sequência: "Um bocado de pão... Eu pago!..." (FONSECA, 1996, p. 86). É interessante notar o contraste entre "um homem gordo e alto", que "segura a barriga" (FONSECA, 1996, p. 86) e a custo, com palavras entrecortadas pelo riso, consegue falar e pede que $o$ lancem à rua, e Zé Limão, com sua "barba crescida, o fato em farrapos escorrendo água” (FONSECA, 1996, p. 85), "pés sujos, plantados ao meio do soalho atapetado" (FONSECA, 1996, p. 85). Zé Limão é atirado à rua e sobre ele incide um vento, imagem recorrente na obra de Manuel da Fonseca, que aqui aparece como imagem da violência exercida sobre os espoliados:

Vai exausto, roçando pela parede molhada. Ao sentir a moeda na mão, uma raiva leva-lhe as últimas forças. Atira-a fora e o tinir do metal nas pedras da rua parece-lhe o riso dos homens do clube. Uma gargalhada curva como um redemoinho de vento. Vento que lhe levava o corpo. Dez bocas enormes soprando um alvoroçado e ameaçador bafo frio.

A cabeça de Zé Limão ardia de febre, a fome roendo no estômago, enovelava-lhe os músculos. Sentia-se cair, cair pelas ruas abaixo em direção ao largo."(FONSECA, 1996, p. 86) 
Mas é importante notar a raiva do personagem, símbolo latente de uma revolta contra sua situação de homem explorado e desprezado, como a de outros tantos personagens das narrativas neorrealistas, raiva esta a ser lida como símbolo de uma ruptura um dia possível. Os significantes ligados à força extrema, à brutalidade e à violência aguda da linguagem, violência expressada também pela aliteração da consoante vibrante $r$, são aqui comuns (roçando, raiva, atirar, tinir, redemoinho, alvoroçado, ameaçador, arder, febre, roer, cair) e contrastam com a suavidade experimentada no fim da narrativa.

É interessante notar ainda a trajetória simbólica do personagem que inicia a narrativa caído, "inerte, com a cabeça entre os braços" (FONSECA, 1996, p. 79) e a custo se ergue ("entesa-se, forçando o corpo" - FONSECA, 1996, p. 84) à procura de comida e vinho, encara erguido, mas de corpo oscilante, os olhares reprovadores do poder e, sem sucesso, deixa-se cair novamente, até seu fim trágico de homem dobrado ("os pés já não assentavam no chão, nem a cabeça” - FONSECA, 1996, p. 87) sobre o poço, quando enfim receberia o descanso possível. A narrativa, verossímil com seu tempo, registra o suplício do homem em luta contra um sistema que lhe priva de tudo, inclusive de sua dignidade, e, incapaz de transformá-lo, se resigna à dor e à renúncia, não sem antes lutar, mesmo que a seu modo. Apesar do registro duro e trágico da condição do homem, o literário, ao fazer incidir sobre o excluído um olhar sincero de registro de sua dor, destina a ele um espaço que não lhe era possível na vida, o espaço da eternidade, o espaço da memória da sua condição miserável de homem do povo, condição esta que o discurso ideológico do Regime Salazarista procurava esconder. A narrativa dá a ele também um sono de descanso, trocando os significantes de teor mais violento e expressivo, por outros de delicadeza e suavidade: "Escorregava-lhe para o lado de dentro do poço, os pés subiam cada vez mais. Zé Limão ia deitar-se e dormir sossegado. A cabeça tombava-lhe suavemente." ( FONSECA, 1996, p. 87).

Trajetória análoga, mas em diferente nível, parece experimentar o protagonista de Seara de Vento, romance do mesmo autor: nele também se dá a ver um indivíduo esfomeado que, em luta contra um sistema que lhe priva de sua condição de sujeito, e após enfrentamento com os meios que lhe são possíveis, é vencido. Mas a morte em luta épica de Palma é posta como símbolo para a aprendizagem de uma revolução realizável no porvir.

António de Valmurado - o Palma - luta para recuperar sua dignidade de pai e provedor de sustento para a família, dignidade esta abalada a partir do momento em que, injustamente acusado de roubo, perde o direito ao trabalho. O início da derrocada da família é marcado pela destruição do forno em que coziam o próprio pão. "É a alma de uma família o forno do pão... A certeza, o sossego, a confiança... O nosso forno!” (FONSECA, 1984, p. 16) - dizia o pai, Joaquim de Valmurado, demonstrando a simbologia do forno como a própria vida da família, visto que através dele mantinha a capacidade de conseguir o sustento próprio e de possuir meios para ser socialmente. 
O forno no romance é ao mesmo tempo metáfora da vida e da morte. É ele que permite cozer o próprio pão garantindo identidade e dignidade à família, mas é também próximo a ele que se enforca o velho Joaquim de Valmurado, por reconhecer que já não havia como lutar para sobreviver sem "a alma da família" que o forno representava, e sem sua courela que lhe fora para sempre tirada. É também na cova do forno que o filho Bento permanece o dia a baloiçar o corpo e a cantar, como se estivesse morto para a vida, numa espécie de estado de latência à espera de um tempo outro. E é nesse mesmo forno que o corpo de Palma irá cair morto, como a simbolizar ambiguamente a morte na luta e o prenúncio de uma vida nova possível através da aprendizagem de uma luta coletiva, necessariamente reiterada pelas palavras finais de sua sogra, Amanda Carrusca.

O forno lembra o trabalho em benefício próprio, através do qual a família Valmurado poderia reconhecer-se. Além disso, por meio dele se faz o pão que sustenta, símbolo da vida, o alimento essencial. Mas a queda do forno aparece como um sinal de mau agouro, visto que nas palavras do narrador é ele que "marca o princípio desses dolorosos acontecimentos" (FONSECA, 1984, p. 17) que envolvem o suicídio do velho Joaquim, a acusação de roubo de António de Valmurado, a sua prisão, a derrocada da família, e, posteriormente, o envolvimento com o contrabando, o suicídio de Júlia, o ataque a Elias Sobral e o cerco a Palma. É nesse sentido que o próprio fato de voltar a pensar em reconstruir o forno - após ganhar algum dinheiro com o contrabando - funciona no romance de modo ambíguo: é o recomeço da ordem familiar, mas ao mesmo tempo uma espécie de mau presságio, como se a história estivesse a recomeçar. Nesse sentido a ideia do círculo vicioso contamina de morte a proposta de vida.

Paradoxalmente é lá que Palma irá morrer - "Logo tomba, desamparado, para dentro do forno derruído". (FONSECA, 1984, p. 172) como a simbolizar com sua morte a luta que tem que ser empreendida contra a dominação, mesmo que em seu caso ela não tenha sido plena, porque individual. Mas é a partir de sua morte em espetáculo - lembremos que ela é assistida pelos camponeses que avançam sempre apesar das ordens da guarda - que a compreensão da verdadeira luta é possível, como a anunciar a esperança e o nascimento de um futuro melhor, mas sem idealizações.

Esse herói desorientadamente épico é projetado no plano maravilhoso (necessário ao épico) através do uso frequente de símbolos, como o vento, que envolve de magia a referencialidade textual. A luta épica de Palma, representativa da sua fome de liberdade e de dignidade, é ampliada ainda pela reiteração das condições adversas às quais o personagem é submetido, e contra as quais permanece em luta, atribuindo grandiosidade épica às suas ações. Isso ocorre não apenas nas partes em que se narra seu combate singular contra a guarda, ao final do romance, em luta contra forças de valor muito desproporcional. As cenas do capítulo 10, em que a narrativa descreve sua primeira ida ao contrabando, para poder sustentar a família, embora não concordasse com a prática, já que sempre ganhara o "pão à 
luz do Sol, de cara levantada" (FONSECA, 1984, p. 60), acentuam a peleja do personagem não apenas contra o cansaço proveniente do esforço físico despendido na atividade (ressalte-se que a narrativa faz questão de marcar as grandes dificuldades do percurso: a volumosa carga, o escárnio do colega de empreitada, Banaíça, o caminho escuro, a lama, a nortada que lhe morde na pele, o frio gélido, o chão inclinado, a vereda tortuosa e resvaladiça, a erva molhada, a íngreme descida, a travessia do rio Chança de água gelada, o suor, entre outras imagens recorrentes no capítulo - cf. FONSECA, 1984, p. 63-72), mas também contra o seu próprio corpo faminto, numa sequência que, de certo modo, reescreve ficcionalmente os percalços enfrentados por Jesus nos últimos acontecimentos até a sua morte.

O protagonista desta nova via crucis (para usar a expressão consagrada pelo cristianismo católico) é Palma, um homem comum. A fome o assola. Em quatro momentos diferentes ao longo do capítulo, o narrador faz questão de salientar que o personagem segue em luta contra o peso da carga e a travessia perigosa e cansativa, e também contra a dor de um estômago vazio, o que ajuda a ampliar sua heroicidade, nessa cena de grandeza épica singular, porque de outra natureza, mas também exemplar. Primeiramente, cita o narrador: "Uma dor aguda rói o estômago vazio do Palma. Mal sente já as pernas, as correias enterram-se-lhe nos sovacos. De braços erguidos, quebrado pela cintura, crava os dedos na carga, por cima da cabeça, e segue a passo estugado." (FONSECA, 1984, p. 66). Mais adiante ressalta: "A cada pancada dos pés contra o chão, o Palma sente a dor do estômago percutir-lhe por todo o corpo. Subitamente, nota o grande silêncio que o cerca e com ele caminha. A nortada agora é lenta, cortante como um sopro gélido." (FONSECA, 1984, p. 69). Quase ao final da sofrida travessia, o narrador reitera: "Muito fina, a dor continua a roer-lhe o estômago, a cabeça escalda-lhe. Grossas bagas de suor escorrem-lhe da cara, saltam a cada passada brusca." (FONSECA, 1984, p. 71). Por último, é o próprio Palma que suplica ao chefe da empreitada, reiterando sua dor: "Tu não vais pôr-me de lado... - A voz estrangula-se na garganta. - Não!... Quando eu comer todos os dias, posso tanto quanto os outros!" (FONSECA, 1984, p. 72).

Esse novo martírio empreendido simbolicamente pelo personagem de Manuel da Fonseca pode ser posto em paralelo à cena registrada no romance Levantado do Chão, de José Saramago, texto de 1980 considerado pelo próprio autor como seguidor das propostas estéticas neorrealistas. A cena do personagem João Mau-Tempo carregando um enorme tronco de madeira, com vistas a não permitir que os outros trabalhadores dessem parte dele como fraco, relembra a caminhada de Cristo carregando a própria estaca de tortura. Entretanto, o narrador saramaguiano nesse momento faz questão de salientar a fome enfrentada pelo personagem e comenta de modo crítico que a diferença fundamental das duas cenas está no fato de a primeira ter sido considerada exemplar e segunda ser ignorada pela história:

Grandes declamações se fazem desde há dois mil anos por ter levado Cristo a cruz ao Gólgota, e com ajudas do Cirineu, e deste crucificado que aqui vai ninguém fala, ele que 
mal ceou ontem e quase nada comeu hoje, ainda com meio caminho por andar, já os olhos se lhe turvam, é uma agonia, senhores, (...) (SARAMAGO, 1999, 76).

João Mau-Tempo começa a adquirir, assim, estatuto de herói épico pela grandiosidade da ação - mesmo que numa ação absurda e sem comprometimento político que a valide ideologicamente - e pela comparação metafórica com a cena do martírio de Cristo. Assim como Manuel da Fonseca, a narrativa de José Saramago atribui a esses personagens marginais da História um registro de existência, narrando as vidas duras de homens comuns, que não detêm nenhum sinal distintivo que os assinale como heróis tradicionais, mas que nobremente defendem a causa da justiça e de uma vida digna. A grandiloquência épica é conseguida especialmente por esse registro de luta pela sobrevivência, apesar de forças tão adversas, e engrandece esses novos heróis dessa nova e des-orientada epopeia.

No romance Seara de Vento, outra cena importante ligada às imagens relacionadas ao alimento é a que se apresenta nos capítulos 5 e 7. A cena já tinha sido descrita em forma de conto pelo autor em "Meio pão com recordações", reunido em O Fogo e as Cinzas, obra publicada primeiramente em 1951. Mas a interrogação final do conto ganha resposta no romance, ampliando a tragicidade da cena, por eliminar a suposição pelo desfecho falhado da ação.

No conto e nos capítulos do romance, destaca-se a conversa entre Júlia, a esposa de Palma, e sua mãe, Amanda Carrusca, no momento em que preparam umas "sopas d'alho"( FONSECA, 1984, p. 33) com o pão retirado à força das mãos do neto Bento, que o ganhara como esmola, enquanto, desejosas de que Palma matasse um coelho ("Ao menos, hoje enchíamos a barriga”, deseja Júlia - FONSECA, 1984, p. 33), esperam pelo homem que fora caçar. Quase toda a narrativa de Seara de Vento é marcada pelas imagens sombrias e de mau agouro, o casebre e a família aparecem fustigados pelo vento, envolvidos por uma obsedante atmosfera de penumbra (lareira apagada, vestidos pretos, sombras espessas, parede negra, frouxa claridade - imagens destacadas do primeiro capítulo), significantes logicamente relacionados com suas próprias vidas sumidas, reduzidas pela exploração e dominação social. Tais imagens também estão presentes na cena do capítulo 5, por exemplo, logo no início: "A momentânea animação some-se, aos poucos, no ambiente penumbrático" (FONSECA, 1984, p. 33). Nesse momento, Amanda Carrusca acende a lareira e ambas conversam à luz do fogo, rememorando experiências do tempo em que comiam pedaços de toucinho dados pelos lavradores ou de que se serviam nas casas dos patrões na vila. As imagens evocativas das lembranças de um tempo em que enfrentavam menos fome não chegam a denotar uma suspensão do tom trágico da narrativa, mas cortam com uma certa leveza o tom pesado da expectativa vivida por ambas à espera do resultado da caçada, ao mesmo tempo em que ajudam a denunciar a mudança dos tempos, para uma época em que os lavradores não mais davam nada aos pobres ("Aquela raça de lavradores antigos acabou-se...”- FONSECA, 1984, p. 37). 
A narração da cena (descrita sequencialmente no conto "Meio pão com recordações") é intercalada com as cenas da caçada de Palma, relatadas no capítulo 6 , e retomada no capítulo subsequente, marcado novamente pelos tons escuros e sombrios, como a comparação do lenço de Amanda Carrusca assemelhado a uma "enorme crista negra" (FONSECA, 1984, p. 46), e pelos tons de vermelho (as "manchas vermelhas que afloram na pele” - FONSECA, 1984, p. 46 - da velha, após ser atacada por Bento, e o fogo da lareira). De fato, toda a narrativa é essencialmente pictográfica. A plasticidade das imagens faz com que estas sejam facilmente marcadas nas retinas do leitor. Por isso, não é difícil compará-las a outras imagens eternizadas pela pintura neorrealista, que, como a literatura, representará o homem em situações comuns do dia a dia, apresentando uma simplicidade que se pode transformar em beleza estética.

De fato, em 1945, o pintor Marcelino Vespeira defendia em sua "Carta aberta aos Pintores Portugueses", publicada no suplemento A Tarde: "Façamos pintura para todos, que todos nos olhem como homens. É este o nosso dever". O que nos parece claro a respeito da pintura neorrealista portuguesa é, para além das diferentes experimentações e soluções de seus diferentes artistas, em nível formal e estético, um desejo comum de representação do homem, nas suas várias práticas habituais, não a sua apresentação bucólica, idealizada, mas o seu agir, seus gestos de trabalho e de luta diária pela sobrevivência, suas ações cotidianas comuns, o labor em situações de exploração, as imagens de desespero e de desilusão, mas também imagens de inconformismo e de apelo pela justiça.

O olhar de angústia e dor dos personagens, as mãos crispadas, os rostos contraídos e fechados, as faces sombrias, os gritos atormenta-

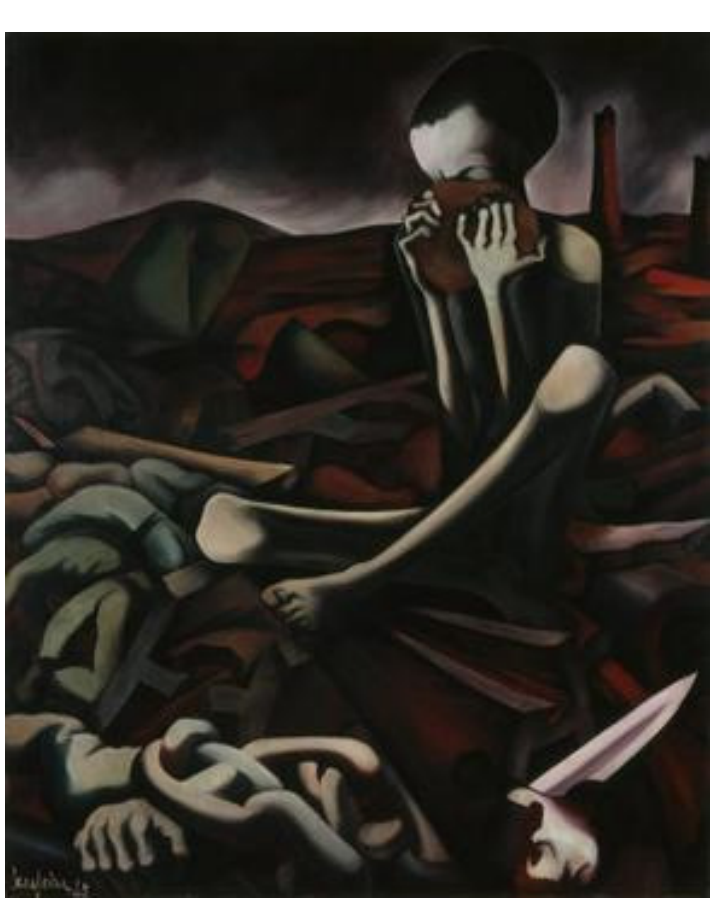

dos, facilmente encontrados nas descrições do romance de Manuel da Fonseca, são reiteradamente perceptíveis também em quadros como os de Lima de Freitas e Querubim Lapa, ou na emblemática composição Apertado pela Fome (de 1945), de Marcelino Vespeira, em que a imagem soturna de iluminação intensamente dramática, em tons de vermelhos escuros, preto e cinza, retrata uma criança excessivamente magra e abandonada que cobre o rosto em meio a destroços e corpos, imóvel pela dor da fome e pelo sofrimento advindo como consequência imediata, neste caso, da guerra. 
Mas gostaria de lembrar a pintura de Júlio Pomar, Almoço do trotha (1946-1950), tornado uma espécie de quadro-manifesto do Neorrealismo português, em que se nota uma denúncia à condição precária dos trabalhadores, neste caso, um empregado da construção civil, no descanso para o almoço, acompanhado da família. A pintura marcada pelos tons escuros que definem o ambiente e pelo enquadramento da imagem através de uma visão bem próxima às figuras humanas, destacadas do espaço pelo branco e pelo vermelho de suas vestes, exemplifica

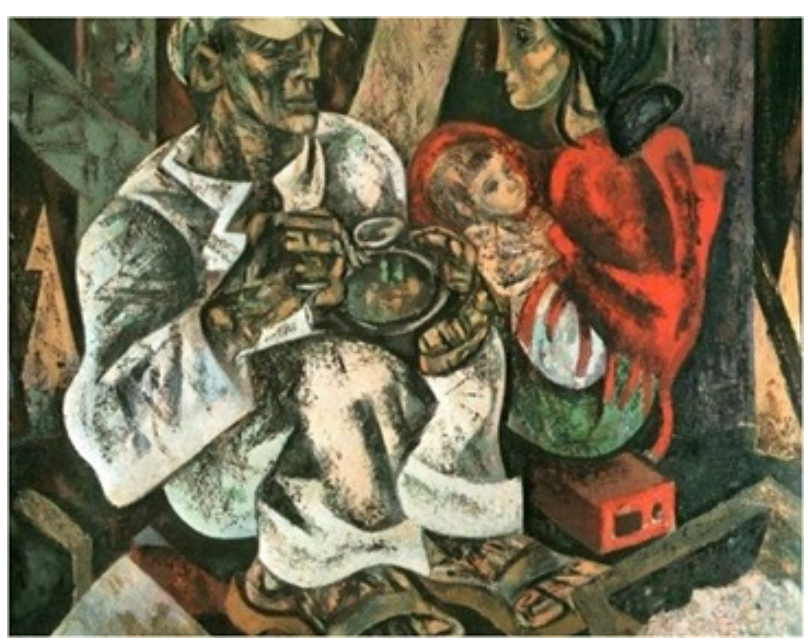
o cuidado do pintor em retratar a beleza da figura humana comum imersa no social. As figuras trocam entre si um intenso olhar que comove o espectador e o obriga a pensar sobre aquela condição. A organização do espaço, apertado e quase claustrofóbico, denotado pela postura dos personagens, acocorados sobre tijolos, sem poder nem mesmo esticar as pernas, e pela imagem muito próxima do observador, que não revela o final das cabeças das figuras representadas, denuncia a condição de cerceamento do sujeito, seus corpos, encolhidos e expectantes, de figuras anônimas do mundo do trabalho. Entretanto, o branco e o vermelho de suas vestes podem aqui simbolicamente insinuar a possibilidade de perversão dessa condição.

O vermelho é também a cor salientada pelo narrador do romance Levantado do Chão, de José Saramago, na cena em que o jovem Manuel Espada "luta" contra a máquina debulhadora do trigo e do homem. Mas aqui a simbologia da cor vermelha aparece com outro sentido, pois o narrador arrazoa sobre a justa cor que o pão deveria ter, uma vez que, para ser produzido, consome o sangue do trabalhador. A cena apresenta o personagem Manuel Espada pela primeira vez, participando de uma insurreição (assim chamada pelos donos do latifúndio) com mais quatro rapazes, abandonando o trabalho contra uma debulhadora de trigo. O narrador introduz a cena com uma estratégia cinematográfica de focalização do olhar em plano figura, centrando o olhar do leitor na máquina que serve como instrumento de opressão:

Também complicada, por exemplo, parece esta máquina, e é tão simples. Chamam-lhe debulhadora, nome desta vez bem posto, porque precisamente é isto que ela faz, tira os grãos da espiga, palha para um lado, cereal para outro. Vista de fora, é uma grande caixa de madeira sobre rodas de ferro, ligada por uma correia a um motor que trepida, estrondeia, retumba e, com perdão, fede. (SARAMAGO, 1999, p. 99-100) 
Note-se que o narrador se coloca em cena estando próximo à máquina, o que se percebe pelo uso do pronome demonstrativo esta. Os significantes sensoriais, ligados ao olhar (a descrição visual da debulhadora), à audição (indicativos do barulho que ela faz) e ao olfato (ao mencionar que seu motor fede) ampliam a percepção que o leitor tem da cena, tornando-a mais próxima dele, presentificada e, portanto, ainda mais cinematográfica.

Após descrever um pouco mais a caixa amarela e chamar a atenção para a poeira que ela forma, a estratégia é a da abertura de focalização do ponto de vista da câmera para um campo longo em que a distância é panorâmica, embora se pretenda realçar algo que irá despertar a atenção do espectador: "Há uns vultos no meio desta névoa. Estiveram todo o dia nisto, e ontem, e anteontem, e mais para trás, desde que a debulha começou, são cinco, um mais velho, quatro de pouca idade [...]" (SARAMAGO, 1999, p. 100). Destacam-se homens sob uma névoa de poeira, que até faz lembrar o nevoeiro que marca o conto "Névoa", de Manuel da Fonseca, ou uma certa névoa indicativa da opressão em O Delfim, romance de José Cardoso Pires. Com isso, a narração começa a deslocar o foco, posto sobre a máquina, para os homens. Adiante volta a absorvê-la em plano figura para ampliar no leitor a sensação de que tais homens sofrem quase que engolidos pela debulhadora:

A boca da máquina é um vulcão para dentro, um gasgarro de gigante, e é o mais velho dos cinco que mais tempo a alimenta. (...) Desce o mais velho, sobe um dos novos, e a máquina é como um poço sem fundo. Só falta meter-lhe um homem dentro. Assim o pão apareceria com a sua justa cor vermelha, e não de inocente branco ou pardo neutro. (SARAMAGO, 1999, p. 100)

É de notar que a máquina aparece animizada, como uma espécie de monstro engolidor, que, ao invés de alimentar o homem, é alimentado por ele. No final do trecho citado, o comentário dialeticamente fundamentado do narrador faz perceber a totalidade das relações implicadas numa ação cotidiana que é um homem comer um pão. Normalmente não se pensa na quantidade de homens cuja força de trabalho está envolvida nisso. Como mostrou o estudo de Teresa Cristina Cerdeira (Silva, 1989), José Saramago insere o humano no divino, tornando o sacrifício do homem paralelo ao sacrifício de Cristo: o pão e o sangue do trabalhador simbolizados nessa nova hóstia de "justa cor vermelha".

Nessa mesma narrativa, são recorrentes as imagens ligadas à fome e à privação, de alimento, de liberdade e de dignidade. A cena retratada na venda, em que uma mulher e seu marido suplicam pela venda fiado da comida, feridos na sua autoestima, é um exemplo comovente. O próprio narrador não é capaz de se negar ao tom compassivo e recorre, primeiramente, ao comentário emotivo ("Chega o sábado e traz a féria, mas tão mesquinha ela e que não se vê nem sabe como aviar o farnel para a semana seguinte, arrepia-se uma pessoa mesmo não estando frio." - SARAMAGO, 1999, p. 
82, grifo nosso), e, mais adiante, à justificação da evasão que empreenderá, apondo, em sequência à cena do avio, histórias de tesouros escondidos ("Por causa destas faltas e outras semelhantes é que nos pomos a inventar histórias de tesouros escondidos, ou já as encontramos inventadas, sinal de muita necessidade antiga, não é só de hoje.” - SARAMAGO, 1999, p. 84). A luta diária pela sobrevivência em um trabalho de sol a sol, com o estômago a apertar, e a fome de um pagamento mais justo pelo trabalho realizado são exemplos que também poderiam ser explorados. Nota-se ainda no romance a experiência literária de uma realidade denunciada pelos textos não-ficcionais da época, a de que os homens que - aturdidos pela fome e pela miséria - se revoltassem, eram pagos não com pão e trabalho, mas com coronhadas, prisões e mortes, como o caso citado pelos escritores do texto de denúncia $A$ fome em Portugal. ${ }^{4}$ Os limites deste artigo, no entanto, não permitem explorar tantas cenas do romance com detalhamento.

Gostaríamos, no entanto, de salientar brevemente algumas cenas ligadas ao alimento nas obras de José Cardoso Pires, autor da contemporaneidade portuguesa, que não nega a fundação ética de seus romances nas veias do Neorrealismo. No romance O Anjo Ancorado, de 1958, mesmo ano de publicação de Seara de Vento, lê-se o interessante contraste entre duas caçadas: a submarina realizada por João - personagem-metonímia de uma camada de elite intelectual que tem as esperanças esmagadas pelo fascismo e abandona a ação política, acomodando-se, ou melhor, ancorando-se -, caçada esta marcada por violência e inutilidade, já que sem justificativa produtiva e fundada em aparato mecânico de alto nível para matar um peixe que não oferece resistência; e a caçada de "um velho muito velho que corria atrás dum perdigoto sem conseguir deitar-lhe a mão" (PIRES, 1998, p. 111), numa luta acirrada, e sem aparatos mecanizados de auxílio, contra várias forças diferentes: a presa ("um perdigoto lutador, honra lhe fosse feita” - PIRES, 1998, p. 111), as condições bravias do terreno, o próprio corpo cheio de fadiga, o outro que "lhe quisesse disputar a caça"( PIRES, 1998, p. 111), e, a seguir, contra os visitantes da cidade, como Guida que desejara que este soltasse a caça. A narração detalhada da luta do velho para vencer e conseguir o alimento desejado, especialmente destacada nos capítulos $15^{\circ}$ e $17^{\circ}$, acentua, também nesta narrativa, a grandeza épica de pessoas comuns, na sua luta pela sobrevivência. $O$ velho - sagaz e ladino na sua conquista do perdigoto -, capaz de vencer também a ingênua Guida, através da burla, é o exemplo da vitória da trapaça fundada na astúcia, símbolos da aposta clandestina na subversão de um poder maior através da luta possível. Ao vazio de alma e ação de uma elite repleta de facilidades, Cardoso Pires opõe o excesso de sagacidade e atividade de uma classe oprimida e desprovida de bens e regalias sociais.

Apreciador da escrita de Ernest Hemingway, Cardoso Pires parece escolher como intertexto latente de $O$ Anjo Ancorado o romance $O$ Velho e o Mar, que narra a luta de um velho pescador em alto-mar, primeiramente para conseguir fisgar um peixe que lhe traga algum alimento 
e lucro e depois para matá-lo e retirá-lo do mar e, como não era possível, devido ao tamanho descomunal do espadarte pescado, mantê-lo junto ao barco. Atacado por tubarões, o exausto velho chega à praia com o peixe já sem carne, mas a trágica narrativa salienta a luta do homem pela vida e contra a própria sorte, destacando a perseverança e o saber da experiência. Em Cardoso Pires, aparece também uma cena de pesca de um enorme peixe - um mero -, mas, longe de salientar a grandiosidade do pescador João, em tudo oposto ao protagonista de Hemingway, a narrativa desloca para o velho caçador do perdigoto, não exatamente a hombridade do pescador da obra americana, incapaz de trapacear para vencer, mas o engenho e a perseverança para a manutenção de sua vida.

No prefácio ao livro Jogos de Azar, intitulado "A charrua entre os corvos", de 1963, José Cardoso Pires ressaltou que, apesar de o tema da fome não mais seduzir os escritores da sua contemporaneidade - em suas palavras, "a fome elementar é cada vez menos um tema da Literatura" (PIRES, 1985, p. 9) -, "a vida primária e a desigualdade primária” continuavam a existir e não poderiam ser ignoradas. Salienta:

Devemos reduzi-las à sua explicação 'física' ou à responsabilidade colectiva?

Penso que não. Penso que elas dispõem de dimensões morais, isto é, literárias, que as ampliam de significado e as não limitam à mera patologia social. A fome não é apenas um problema de sobrevivência, é uma questão de impossibilidade do exercício das capacidades do homem e do seu rendimento como tal. (PIRES, 1985, pp. 9-10)

É talvez por observar a fome a partir de uma outra ótica, como uma certa "destruição que se exerce, não imediatamente sobre ele (o homem), criatura física, mas sobre os instrumentos que o rodeiam, sobre os gestos e sobre as manifestações de actividade que o tornam utilizável como homem" (PIRES, 1985, p. 10), que a escrita cardosiana continuou a investir em gestos de testemunho contra a amputação do homem, contra essa outra espécie de fome, continuou a ressaltar que "o indivíduo destituído de autoridade está condenado a tropeçar a cada passo nos caprichos daqueles que a detêm como exclusivo" (PIRES, 1985, p. 12). É talvez um tanto por isso que seu romance, $O$ Delfim, manteve-se atrelado a dimensões morais e pôde então ensaiar uma celebração de conquista da perversão da ordem social.

Assim, por último, gostaríamos de analisar algumas imagens geradas pelo alimento, agora como símbolo de uma revolução conquistada no nível do narrado, que é projetada como alegoria de um outro Portugal possível, na obra O Delfim. O romance é publicado em 1968, quando o tempo histórico, mais do que no tempo da escrita de Manuel da Fonseca, já permitia acreditar um pouco mais na concepção mutável do tempo e do espaço social ligado a ele. Talvez seja por isso que, no enunciado, os habitantes da Gafeira celebram em festa a profanação da imagem do Engenheiro e a posse da lagoa, numa imagem simbólica de substituição do poder 
individual pelo coletivo, imagem que parece apontar para o desejo de um outro Portugal a conquistar, no tempo da escrita do romance, marcado por um regime totalitário.

$\mathrm{O}$ "festim das enguias" aparece na narrativa como um verdadeiro tempo da transgressão, no sentido dado por George Bataille, ${ }^{5}$ não só porque é a comemoração da ruptura com uma velha ordem, mas também porque aparece como tempo da libertação, da manifestação de um desejo reprimido por tanto tempo de cerceamento. Assim, não é gratuito que a narrativa de $O$ Delfim apresente um narrador instalado num quarto, perscrutando a memória com vias a entender o que talvez se tenha passado na localidade da Gafeira, e supostamente desejoso de desvendar um crime, a quem chegam os fumos de um festim comemorativo, imagem do tempo da transgressão, do tempo do desvio: em termos ideológicos, o verdadeiro tema básico da narração. O narrador ousa também uma excursão do seu objetivo inicial ao vir à Gafeira e, seduzido, escolhe abandonar a caçada, mas comparecer à festa. Situemos seu texto pervertedor da ordem:

O que conta é o festim das enguias e logo, a meio da tarde, o arraial dos Noventa e Oito, com tachos de cebolada a crepitar ao ar livre, vinho e concertinas. Isso, sim, é que é a caçada de hoje. Conta mais que o melhor cinturão de galeirões de crista, admitindo que ainda há bichos de tal espécie à face da terra e que não ficaram todos sepultados nos manuais.

Está dito, ao arraial não falto, custe o que custar. (PIRES, 1983, p. 183)

Em meio a um "nevoeiro que embriaga" (PIRES, 1983, p. 129) pela névoa que vem da lagoa e pelo fumo que vem das enguias a arder no fogo -, desvenda-se um novo encoberto também ressignificado: as lagartixas da história a sacudirem-se do seu sono de pedra. O fogo, elemento escatológico, marca a destruição de um mundo e a descoberta, ou irrupção, de outro, destruindo e purificando. $\mathrm{O}$ fumo, a gordura que chia no fogo e as labaredas lembram também imagens de sacrifícios religiosos oferecidos para a expiação de pecados ou para oferendas, podendo ser associadas à purificação e à abertura para um novo tempo, já que permitem lembrar uma espécie de quitação com um tempo anterior (através da expiação pelo sacrifício) e uma inauguração de um novo, possibilitado pela oferta sacrificial:

Um fumo áspero, de gordura a chiar no fogo, sai das labaredas e das quelhas. As enguias, grossas como punhos, estorcem-se nos espetos de salgueiro, pingando nas brasas e abrindo labaredas. Na chaminé do humilde, no balcão mais tosco, rompem clarões, ao mesmo tempo que nuvens violentas, carregadas de um sabor bárbaro, rolam sobre as cabeças dos homens e vêm até mim.

Baixo a vidraça, mas, ouvindo através dela a balbúrdia da rua, preparo-me para uma noite difícil. Enquanto não adormecer vou pensar certamente no tema "Toda a festa é uma demonstração de poder”, e daí sairá um caudal de lembran- 
ças nocturnas - Regedor, política, cosmonautas, amor, coisas boas. De raciocínio em raciocínio irei longe, darei voltas para chegar à casa do Engenheiro conquistada pelas lagartixas, que são, para mim, o tempo (português) da História. (PIRES, 1983, p. 128-129)

A oferta sacrificial simbólica, com gosto especial de vingança, seria justamente o Engenheiro Tomás Manuel, sacrificado através do corpo de seus cães, na cena grotesca em que um outro velho, o Velho cauteleiro, arranca-lhes "tiras de carne a todo o comprimento dos lombos, que saem vivas, a saltar, e se enroscam" (PIRES, 1983, p. 130) no seu braço: "Enguias, meus senhores. Aproveitem a hora da sorte, anuncia, mostrando-lhes bem alto para que todos as apreciem." (PIRES, 1983, p. 130). Quem não pode com o dono, vinga-se no cão, dissera uma vez o Engenheiro. Assim, o sadismo do Velho, retalhando os cães com suas unhas e "puxões ansiosos", e, portanto, com evidente gozo erótico, aparece como a imposição da nova era. Mostra que essa violência - em si absurda - é simbólica: é preciso sacrificar o mundo antigo para criar o novo.

Ao longo deste estudo, procuramos recortar imagens geradas pelo alimento em obras do Neorrealismo em Portugal, por entender que tais imagens constroem juntas um painel de documentação do tempo português, marcado pela privação e pela censura dos anos de salazarismo, mas também compõem uma grande tela em que se fixam retratos de imposição da vida através da luta pela sobrevivência e do exercício revolucionário de defesa da mudança do status quo. Mas, sendo arte - literária ou pictórica - em linguagem, estes gestos e vivências não se restringem apenas a uma atmosfera datada, mas a qualquer tempo em que o sujeito é desprovido de sua condição básica de subsistência, de sua liberdade e de sua dignidade e a qualquer realidade em que se faça do poder um exercício impositivo de autoridade. Enquanto não mudarem as relações de dominação na sociedade, a arte que não descuida de um diálogo com o tempo continuará a pintar imagens contra a violência ao pensamento e à vida, continuarão a existir poetas que desejam "Que o pão encontre na bocal o abraço de uma canção", "Não a fome fatigada/ de um suor que corre em vão", porque sabem, como o escritor bíblico de Eclesiastes, o sábio Rei Salomão, "que não há nada melhor para (os homens) do que alegrar-se e fazer o bem durante a sua vida; e também que todo homem coma e deveras beba, e veja o que é bom por todo o seu trabalho árduo" (Eclesiastes 3:12,13). E porque também sabem, como o pintor Júlio Pomar sabia, que a obra de arte é

um poderoso e apaixonado meio de conhecimento, uma forma superior de comunicação, um instrumento que o homem tem a seu alcance na luta contra a alienação. A obra de arte digna desse nome é sempre um instrumento de progresso, é um testemunho de campos sempre novos e arrancados pelo espírito às forças que o negam. (POMAR, 1951). 


\section{REFERÊNCIAS BIBLIOGRÁFICAS}

BATAILLE, Georges. O Erotismo. Trad. João Bernard da Costa. 3ed. Lisboa: Edições Antígona, 1988.

FONSECA, Manuel da. Aldeia Nova. 10. ed. Lisboa: Editorial Caminho, 1996.

. Seara de Vento. Lisboa: Caminho, 1984.

. O Fogo e as Cinzas. 10ed. Lisboa: Editorial Caminho, 1983.

MATTER, Michele Dull Sampaio Beraldo A excursão neo-realista: o lugar do literário na tradição da utopia. Rio de Janeiro: UFRJ/ FL, 2010.

PIRES, José Cardoso. A charrua entre os corvos. In: Jogos de Azar. 5. ed. Lisboa: O Jornal, 1985. pp. 7-12.

. O Anjo Ancorado. Lisboa: Publicações Dom Quixote, 1998.

. O Delfim. 2ed. Rio de Janeiro: Civilização Brasileira, 1983.

POMAR, Júlio. Ver, Sentir, etc. In: Vértice, n. 95 - Julho de 1951.

RODRIGUES, E.; NEVES, R das. A fome em Portugal. São Paulo: Ed. Germinal, 1959.

SARAMAGO, José. Levantado do Chão. 7. ed. Rio de Janeiro: Bertrand Brasil, 1999.

SILVA, Teresa Cristina Cerdeira da. José Saramago entre a história e a ficção: uma saga de portugueses. Lisboa: Publicações Dom Quixote, 1989.

Recebido para publicação em 17/11/2013

Aprovado em 08/02/2014

\section{NOTAS}

1 No referido prefácio ao livro A fome em Portugal, o Professor Josué de Castro mencionara a respeito da obra que prefaciava: "Não se trata - devo dizer de logo - de um ensaio científico, nem mesmo de uma análise sociológica orientada dentro dos princípios da moderna sociologia. A fome em Portugal, na acepção dos autores, simboliza a mortificação coletiva do povo português, frustrado em suas aspirações mais íntimas por um regime ditatorial inteiramente desvinculado dos interesses coletivos os mais legítimos e os mais autênticos. A fome de que trata êste livro não é apenas a de alimentos, mas também a de liberdade e de dignidade humana." (in RODRIGUES; NEVES, 1959, p. 11). Faço questão de citar o excerto que ajudou a definir boa parte do corpus de análise deste artigo, uma vez que as obras selecionadas também abordaram a fome não apenas de alimentos, mas de liberdade e de dignidade. Esse livro de teor jornalístico, que apresenta dados e estatísticas sobre o tempo vivido por Portugal com o qual de outra forma, por veias literárias, já tivéramos contato, é um interessante instrumento de denúncia do regime salazarista publicado no Brasil, onde seus autores emigrados de Portugal viviam e onde ainda era possível publicar obras do tipo, apesar dos esforços insidiosos de silenciamento denunciados pelo autor em sua Introdução de curioso e irônico título: “Os portugueses são um povo inferior: indigno de liberdade e só merecedor da fome, da albarda e da chibata" (RODRIGUES; NEVES, 1959, p. 15-30). 
2 Cf. MATTER, Michele Dull Sampaio Beraldo A excursão neo-realista: o lugar do literário na tradição da utopia. Rio de Janeiro: UFRJ/ FL, 2010.

3 A este respeito, lemos na obra já citada A fome em Portugal: "O esfomeado povo português vive de esmolas, marcha descalço pelas estradas construídas com esmolas, veste-se de esmolas, é curado nos hospitais por esmola e recebe, por esmola, pequeno salário. Em Portugal há três categorias de mendigos: o mendigo oficial, o mendigo por caridade e o mendigo faminto. Este último está proibido de exercer a sua profissão. A Polícia prende-o sempre que o encontra estendendo a mão à caridade." (RODRIGUES; NEVES, 1959, pp. 55-56)

4 A este respeito é interessante citar a denúncia dos autores da já referida obra $A$ fome em Portugal, no fragmento 17, intitulado "Em vez de pão e trabalho, o ditador distribui ao famélico povo coronhadas e balas dos pretorianos" (RODRIGUES; NEVES, 1959, pp. 90 92), do qual recortamos um segmento a título de exemplo: "Valongo é uma vila perto do Pôrto, cuja população vive exclusivamente das minas de ardósia, as quais, até 1941, eram exploradas pelos inglêses. Na fase final da guerra, foram suspensos os trabalhos e lançada na miséria tôda a população. Depois de haverem empenhado os últimos trapos com que cobriam o descarnado corpo, resolveram os trabalhadores desempregados mendigar, do que resultou serem prêsos parte dêles (...), voltando os restantes aos lares, onde, havia meses, não ardia fogo para preparar, ao menos, uma sopa. Finalmente, quando já não era possível agüentar mais, surge a revolta do estômago, levando aquela pobre gente a implorar de joelhos, em frente dos automóveis que passavam escarnecendo aquele quadro de miséria. Perturbada a burguesia no seu parasitário sossêgo, pede providências às autoridades, que mandam ao local a Guarda Republicana, a qual principiou por espancar aquele montão de farrapos humanos." (RODRIGUES; NEVES, 1959, pp. 90-91).

5 Como aprendemos com George Bataille, o homem pertence a dois mundos entre os quais, queira ou não, sua vida está repartida: o mundo do trabalho e da razão, que é a base da vida humana, e que se estrutura a partir da proibição, ou interdito; e o mundo da violência, o da própria natureza humana, viabilizado pela transgressão. Diz o autor: "A transgressão excede sem o destruir um mundo profano de que é complemento. A sociedade humana não é apenas o mundo do trabalho. Simultaneamente - ou sucessivamente - o mundo profano e o mundo sagrado compõem-na, dela sendo duas formas complementares. $\mathrm{O}$ mundo profano é o mundo das proibições, o mundo sagrado abre-se para as transgressões limitadas. É o mundo da festa, dos reis e dos deuses." (BATAILLE, 1988, p. 58) 